\title{
Seroprevalence of leptospirosis in dogs in urban Harare and selected rural communities in Zimbabwe
}

\author{
Authors: \\ Solomon Dhliwayo ${ }^{1}$ \\ Gift Matope ${ }^{2}$ \\ Lisa Marabini ${ }^{3}$ \\ Keith Dutlow ${ }^{3}$ \\ Davis M. Pfukenyi ${ }^{1}$ \\ Affiliations: \\ ${ }^{1}$ Department of Clinical \\ Veterinary Studies, University \\ of Zimbabwe, Zimbabwe \\ ${ }^{2}$ Department of Paraclinical \\ Veterinary Studies, University \\ of Zimbabwe, Zimbabwe \\ ${ }^{3}$ AWARE Trust Zimbabwe \\ (Pvt) Ltd., Harare, Zimbabwe
}

Correspondence to:

Gift Matope

Email:

gmatope@vet.uz.ac.zw

Postal address:

PO Box MP 167, Mount

Pleasant, Zimbabwe

Dates:

Received: 05 June 2012

Accepted: 14 Sept. 2012

Published: 06 Dec. 2012

How to cite this article: Dhliwayo, S., Matope,

G., Marabini, L., Dutlow, K. \& Pfukenyi, D.M.

2012, 'Seroprevalence of leptospirosis in dogs in urban Harare and selected rural communities in Zimbabwe', Onderstepoort Journal of Veterinary Research 79(1), Art. \#447, 6 pages. http://dx.doi.org/10.4102/ ojvr.v79i1.447
C 2012. The Authors. Licensee: AOSIS OpenJournals. This work is licensed under the Creative Commons Attribution License.
A cross-sectional study was conducted to investigate seroprevalence of canine leptospirosis in urban Harare and five selected rural communities in Zimbabwe and to assess public awareness of the disease. Sera from randomly selected dogs were tested for antibodies to the serovars Canicola, Grippotyphosa, Icterohaemorrhagiae and Pomona of Leptospira interrogans using an enzyme-linked immunosorbent assay. Clinical chemistry was performed on all seropositive and selected seronegative sera to screen for hepatic and renal insufficiency. A questionnairebased survey was conducted in Harare to assess dog owners' awareness of leptospirosis and other zoonoses. Overall, $15.6 \%$ of sera samples tested (39 out of $250 ; 95 \%$ confidence interval [CI]: $11.0 \%-20.2 \%)$ were positive for leptospiral antibodies. A significantly higher $(p<0.05)$ seroprevalence was recorded in urban dogs than in rural dogs ( $25 \%$ vs. $11.2 \%)$. No significant difference in seroprevalence was observed amongst dogs from different rural communities or between sexes of dogs. There was a significant association between seropositivity and hepatic and/or renal insufficiency $(p<0.01$ ), with dogs having hepatic and/or renal insufficiency being approximately twice as likely to be seropositive (relative risk $=1.96$; 95\% CI: 1.3-3.0). Of the dog owners, $78.8 \%(119 / 151)$ were aware of zoonoses. Except for rabies (92.4\%), awareness of leptospirosis (5.0\%) and other zoonoses amongst these owners was low. This study showed that leptospirosis was present and represented a risk to dogs from urban Harare and the selected rural communities in Zimbabwe. Availing training programmes for dog owners would be beneficial in improving disease control and reducing the public health risk of pet zoonoses.

\section{Introduction}

Canine leptospirosis is a worldwide bacterial zoonosis, caused by pathogenic spirochaetes that are currently classified as a single species, Leptospira interrogans, and further subdivided into several serogroups and serovars based on antigenic differences (Ellis 2010; Plesko \& Hlavata 1971; Roach, Van Vuuren \& Picard 2010). The disease is characterised by septicaemia, renal and hepatic diseases, coagulopathies, abortions and other abnormalities, with a fatality rate of $10 \%-20 \%$ in dogs (Cullen, Haake \& Adler 2004; Grooms 2006). Infected dogs may present with renal failure or be carriers of leptospiral organisms in their proximal convoluted renal tubules for 1-2 years in a sub-clinical form from where they are persistently shed in urine (Levett 2001). Following shedding in urine, these bacteria may survive for some months under appropriate conditions (moist or wet environments); however, survival is very poor in dry or cold environments (Adler \& Moctezuma 2010). Transmission generally occurs after a susceptible animal has been exposed directly to leptospires from an infected host's urine or contaminated water, mud or moist soil (Bulach et al. 2006). Shedding animals pose a public health risk to humans who get in contact with urine-contaminated environments, particularly water (Sykes et al. 2011).

Leptospires are maintained by a wide range of primary reservoir hosts, including dogs, rodents, cattle, pigs and wildlife, but may also occur in many other mammals that act as incidental or accidental hosts. Although dogs are the primary reservoir host to the serovars Canicola and Bataviae, they may also be infected with serovars such as Icterohaemorrhagiae, Grippotyphosa and Pomona. It has been postulated that the re-emergence of leptospirosis and changes in the epidemiology of the infecting serovars may be due to urbanisation of rural areas in the 1980s and 1990s, which provided greater opportunity for contact between domestic animals and wildlife reservoirs (Murray et al. 2009). Investigations of the resurgence of canine leptospirosis revealed conflicting findings for risk factors such as age, sex, breed and free-roaming lifestyles of dogs. However, environmental factors such as increased precipitation, warmer temperatures, seasonality of cases, access to raw sewage and drinking from contaminated water sources have been identified fairly consistently as important risk factors for canine leptospirosis (Bulach et al. 2006; Duncan et al. 2012; Ghneim et al. 2007; Sykes et al. 2011). Although leptospirosis caused by the serovars Canicola and Icterohaemorrhagiae has been reported in other animals (Dalu \& Feresu 1997), the prevalence of these and other serovars in dogs has not been studied in detail in Zimbabwe. Owing to a lack of cross-protection amongst the different serovars and reports of other serovars infecting dogs, conducting a sero-survey of canine leptospirosis in urban Harare and rural 
communities in the country was warranted. Furthermore, in spite of the zoonotic importance of the different Leptospira serovars, studies on public awareness of leptospirosis have not been conducted. Therefore, this study was conducted to determine not only the seroprevalence of canine leptospirosis in urban Harare and selected rural communities but also to assess public awareness of the disease.

\section{Materials and methods}

\section{Study location and collection of serum samples}

The study was conducted in urban Harare and five rural communities (Marumani, Machuchuta, Ndhlovu, Kariba and Malipati) in Zimbabwe. In Harare, serum samples were collected from dogs presenting at private veterinary practices for routine elective surgery or ill health. Routine vaccination against leptospirosis is done in most of the urban areas in the country and for the purposes of this study, only dogs with no given history of vaccination were sampled. According to the information obtained from the owners, these dogs were reared in confinement in individual homes.

The Animal and Wildlife Area Research and Rehabilitation trust (AWARE Trust) has been conducting spay and castration campaigns amongst dogs and collected samples in randomly selected rural communities in Zimbabwe. Owing to access to a large number of dog serum samples, the rural communities where the AWARE Trust operates were randomly selected for the study. Hence, serum samples collected by the AWARE Trust just prior to ovariohysterectomy and orchidectomy of apparently healthy dogs with unknown medical histories were used for this study. Currently rural dogs are not vaccinated against leptospirosis and are all considered to be free roaming, which allows for contact with other dogs in the same village.

\section{Testing for canine Leptospira antibodies}

The canine Leptospira antibody test kit (ImmunoComb ${ }^{\circledR}$, Biogal-Galed Laboratories, Israel), designed to determine dog serum immunoglobulin $G$ ( $\operatorname{IgG}$ ) antibody titres to four different serovars (namely Canicola, Grippotyphosa, Icterohaemorrhagiae and Pomona) of L. interrogans, was used in this study. The ImmunoComb ${ }^{\circledR}$ test is a so-called enzymelabelled 'dot assay', which is a modified enzyme-linked immunosorbent assay (ELISA) (http://www.biogal.co.il). Serum samples were tested according to the manufacturer's instructions. Briefly, pooled L. interrogans antigens were used to screen for the presence of antibodies to the four Leptospira serovars. Before conducting the test, the developing plates were incubated for $22 \mathrm{~min}$ at $37{ }^{\circ} \mathrm{C}$. The test was then performed at room temperature $\left(20^{\circ} \mathrm{C}-25^{\circ} \mathrm{C}\right)$ in a 72 -well developing plate (12 columns $\times 6$ rows). A $5-\mu \mathrm{L}$ aliquot of the serum was deposited into each well of only the first row, mixed with the antigens adsorbed onto the lower portion of the comb and allowed to stand for $5 \mathrm{~min}$. The comb was transferred to corresponding wells of the second row where unbound antibodies were washed off. The comb was then inserted into the wells of the third row, which contained an enzyme-labelled anti-dog $\operatorname{Ig} G$ antibody that binds to the antigen-antibody complex at the test spots, and was allowed to stand for $5 \mathrm{~min}$. After two more washes in the wells of the next two rows, the comb was transferred to the corresponding wells of the last row for $5 \mathrm{~min}$, where a colour developed via an enzymatic reaction. Upon completion of the colour development in cells of the last row, the comb was moved back to the cells of the fifth row for 2 min to facilitate colour fixation. The comb was removed and left to dry for up to $10 \mathrm{~min}$. The threshold for determining seropositivity was based on the manufacturer's recommendations. The bottom spot on the comb represented the result of the reaction between the anti-dog IgG antibody and Leptospira serovar IgG antibodies in the samples tested. The colour intensity of the bottom spot, representing the Leptospira serovar IgG antibodies, was then compared with that of the upper positive reference spot. A clear purple-grey dot indicated a positive reaction. The results were read with a calibrated (graded from S0 to S6) colour CombScale provided with the kit. A scale of S3, which is equivalent to a positive immune response at a titre of 1:400 by the microscopic agglutination test was considered as the cut-off level of IgG antibodies (http://www.biogal.co.il). Hence, in this study serum samples with a CombScale score of $\geq$ S3 (i.e. $\geq 1: 400$ titre) were considered as positive for leptospiral antibodies to the tested serovars.

\section{Evaluation for hepatic and renal insufficiency}

Since renal and hepatic insufficiency are features suggestive of leptospirosis (Adler \& Moctezuma 2010), all the leptospiral seropositive and randomly selected seronegative dog serum samples were evaluated for hepatic and renal insufficiency by testing for elevated liver enzymes and/or urea and creatinine levels. Hepatic insufficiency was determined by measuring the activity of aspartate aminotransferase (AST; reference value $<30 \mathrm{IU} / \mathrm{L}$ ), alkaline phosphatase (ALP; reference value $<100 \mathrm{IU} / \mathrm{L}$ ) and alanine aminotransferase (ALT; reference value < $30 \mathrm{IU} / \mathrm{L}$ ). Renal insufficiency was determined through measuring blood urea nitrogen (BUN; reference value $<6 \mathrm{mmol} / \mathrm{L}$ ) and serum creatinine (reference value $<150 \mathrm{mmol} / \mathrm{L}$ ). An automated chemistry analyser (Humastar $180^{\circledR}$, Human Diagnostics Worldwide, Wiesbaden, Germany), which was calibrated and run according to the manufacturer's recommendations, was used to measure liver enzyme activity and creatinine and BUN levels. Positive and negative control sera were obtained from Diagnopath Laboratory (Pvt) Ltd, Harare.

\section{Questionnaire survey regarding dog zoonoses}

A cross-sectional questionnaire-based study was employed to investigate public awareness of dog zoonoses, including canine leptospirosis. A systematic random sampling technique was used to select dog owners attending private veterinary practices in Harare. Questionnaires with multiple choice and open-ended questions were distributed to at least $10 \%$ of dog owners attending each veterinary practice. The questionnaire was designed to obtain information on dog owners' awareness of dog zoonoses, with emphasis on canine leptospirosis and the behavioural practices that may lead to an increased risk of leptospiral transmission. 


\section{Data analysis}

Statistical analyses were performed using Stata version SE 11.0 (Stata Corp., TX, USA). The total number of seropositive dogs was calculated according to sex and origin by considering the total number of samples tested and expressing it as a percentage. The $X^{2}$-test was used to measure differences in proportions between generated categories and $p$-values of $<0.05$ were considered significant. Seropositivity was also analysed according to hepatic and renal insufficiency. The association between seropositivity and hepatic and/or renal insufficiency was evaluated by calculating $X^{2}$, the relative risk (RR) and the 95\% confidence interval (CI) using Win Episcope version $2.0^{\circledR}$ software. For questionnaire data the dog owners' responses were analysed using descriptive statistics (frequencies and proportions) related to awareness of dog zoonoses.

\section{Ethical considerations}

Ethical approval for use of dogs and for all protocols in this study was obtained from the Ethical and the Higher Degrees committees of the Faculty of Veterinary Science. The purpose of this study was well explained to the owners of the dogs, who all expressed consent to participate in the study. Standard operating procedures were followed for collection of blood samples and dogs were provided with adequate clean drinking water.

Questionnaire respondents were selected on a voluntary basis from clients visiting veterinary surgeries. Respondents were entitled to withdraw the consent up to a week of data submission. To protect data, questionnaires were submitted in sealed envelopes.

\section{Results}

\section{Seroprevalence of canine leptospirosis}

The distribution of sampled dogs and their leptospiral seroprevalence according to different categories are shown in Table 1. A total of 250 serum samples were collected and the overall seroprevalence was $15.6 \%$ (39 out of 250 ; $95 \%$ CI: $11.0 \%-20.2 \%)$. Overall, urban dogs from Harare recorded a significantly higher seroprevalence $\left(X^{2}=7.9, p<0.05\right)$ compared to rural dogs. A significantly higher seroprevalence was recorded amongst female urban dogs $\left(X^{2}=9.5, p<0.05\right)$ compared to rural female dogs but there was no significant difference between urban male $\left(X^{2}=0.61, p>0.05\right)$ and rural male dogs. Overall, there was no significant difference $\left(X^{2}=0.149, p>0.05\right)$ in seroprevalence between the sexes (Table 1). For rural dogs, seroprevalence varied from $5.9 \%-17.6 \%$ but the differences were not significant $(p>0.05)$.

The majority (69.2\%) of dogs that tested positive had a titre of 1:400, with $45 \%$ of positive urban dogs recording a titre of 1:800 or higher (Table 2). Two of the positive urban dogs had titres of 1:1600 and 1:3200, respectively, whilst none of the positive rural dogs had a titre above 1:800 (Table 2).
Of the dogs tested for hepatic and renal insufficiency, 22.5\% (18 of 80 ) had both hepatic and renal insufficiency, whilst $10 \%$ (8 of 80 ) had hepatic insufficiency only and 2.5\% (2 of 80 ) had renal insufficiency only (Table 3 ). The median values of serum indicators in these dogs were $25 \mathrm{mmol} / \mathrm{L}$ BUN (range $=6 \mathrm{mmol} / \mathrm{L}-77 \mathrm{mmol} / \mathrm{L}), 202 \mathrm{mmol} / \mathrm{L}$ creatinine $($ range $=47 \mathrm{mmol} / \mathrm{L}-1309 \mathrm{mmol} / \mathrm{L}), 72 \mathrm{IU} / \mathrm{L}$ AST (range $=36 \mathrm{IU} / \mathrm{L}-271 \mathrm{IU} / \mathrm{L}), 284 \mathrm{IU} / \mathrm{L}$ ALP $($ range = $118 \mathrm{IU} / \mathrm{L}-$ $5924 \mathrm{IU} / \mathrm{L}$ ) and $76 \mathrm{IU} / \mathrm{L}$ ALT (range $=38 \mathrm{IU} / \mathrm{L}-372 \mathrm{IU} / \mathrm{L}$ ). Hepatic and/or renal insufficiency presented only in urban seropositive dogs. Of these, 65\% (13 of 20) presented with both hepatic and renal insufficiency, $25 \%$ presented with hepatic insufficiency only and $10 \%$ had renal insufficiency only. The seropositive urban dog for which the highest titre (1:3200) was recorded also presented with the highest ALP value (5924 IU/L). Overall, the results demonstrated a significant association between seropositivity and hepatic and/or renal insufficiency $\left(X^{2}=8.9 ; p<0.01\right)$ and dogs with hepatic and/or renal insufficiency were approximately twice as likely to be seropositive for leptospirosis ( $R R=1.96$; $95 \%$ CI: 1.3-3.0).

TABLE 1: Distribution of Leptospira seroprevalence according to sex and location.

\begin{tabular}{llcccc}
\hline Category & Level & $\begin{array}{c}\text { Number } \\
\text { tested }\end{array}$ & $\begin{array}{c}\text { Positive } \\
\text { All animals }\end{array}$ & $\begin{array}{c}\text { Seroprevalence } \\
\mathbf{( \% )}\end{array}$ & $\begin{array}{c}\mathbf{9 5 \%} \\
\text { confidence } \\
\text { interval }\end{array}$ \\
\hline Urban & Femall & 250 & 39 & 15.6 & $11.0-20.2$ \\
& Male & 42 & 13 & 31.0 & $17.1-44.9$ \\
& Overall & 80 & 20 & 25.0 & $15.6-34.4$ \\
\multirow{2}{*}{ Rural } & Female & 92 & 9 & 9.8 & $3.7-15.9$ \\
& Male & 78 & 10 & 12.8 & $5.4-20.2$ \\
& Overall & 170 & 19 & 11.2 & $6.5-15.9$ \\
\multirow{2}{*}{ Rural } & Marumani & 34 & 2 & 5.9 & $-1.9-13.7$ \\
& Machuchuta & 24 & 2 & 8.3 & $-2.7-19.3$ \\
& Ndhlovu & 54 & 5 & 9.3 & $1.5-17.1$ \\
& Kariba & 24 & 4 & 16.7 & $1.0-32.4$ \\
& Malipati & 34 & 6 & 17.6 & $3.9-31.3$ \\
\hline
\end{tabular}

TABLE 2: The distribution of Leptospira seroprevalence according to location and titre.

\begin{tabular}{|c|c|c|c|c|c|c|c|c|c|}
\hline \multirow[t]{3}{*}{ Category } & \multirow{3}{*}{$\begin{array}{l}\text { Number } \\
\text { of positive } \\
\text { samples }\end{array}$} & \multicolumn{8}{|c|}{ Titre } \\
\hline & & \multicolumn{2}{|c|}{$1: 400$} & \multicolumn{2}{|c|}{$1: 800$} & \multicolumn{2}{|c|}{ 1:1600 } & \multicolumn{2}{|c|}{$1: 3200$} \\
\hline & & $n$ & $\%$ & $n$ & $\%$ & $n$ & $\%$ & $n$ & $\%$ \\
\hline Rural & 19 & 16 & 84.2 & 3 & 15.8 & 0 & - & 0 & - \\
\hline Urban & 20 & 11 & 55.0 & 7 & 35.0 & 1 & 5.0 & 1 & 5.0 \\
\hline Total & 39 & 27 & 69.2 & 10 & 25.6 & 1 & 2.6 & 1 & 2.6 \\
\hline
\end{tabular}

$n$, number of animals.

TABLE 3: The number and percentage of dogs evaluated for hepatic and renal insufficiency according to seropositivity.

\begin{tabular}{|c|c|c|c|c|c|c|}
\hline \multirow[t]{2}{*}{ Category } & \multicolumn{2}{|c|}{$\begin{array}{l}\text { Leptospira } \\
\text { seropositive }\end{array}$} & \multicolumn{2}{|c|}{$\begin{array}{l}\text { Leptospira } \\
\text { seronegative }\end{array}$} & \multicolumn{2}{|c|}{ Total } \\
\hline & $n$ & $\%$ & $n$ & $\%$ & $n$ & $\%$ \\
\hline $\begin{array}{l}\text { Hepatic and renal } \\
\text { insufficiency }\end{array}$ & 13 & 33.3 & 5 & 12.2 & 18 & 22.5 \\
\hline $\begin{array}{l}\text { Hepatic insufficiency } \\
\text { only }\end{array}$ & 5 & 12.8 & 3 & 7.3 & 8 & 10.0 \\
\hline $\begin{array}{l}\text { Renal insufficiency } \\
\text { only }\end{array}$ & 2 & 5.2 & 0 & 0 & 2 & 2.5 \\
\hline $\begin{array}{l}\text { No hepatic or renal } \\
\text { insufficiency }\end{array}$ & 19 & 48.7 & 33 & 80.5 & 52 & 65.0 \\
\hline Total & 39 & 100 & 41 & 100 & 80 & 100 \\
\hline
\end{tabular}

$n$, number of animals. 


\section{Questionnaire responses}

A total of $75.5 \%$ (151 of 200) dog owners contacted responded. The gender distribution was roughly equal (52\% men vs $48 \%$ women) and most respondents $(80.8 \%)$ were older than 21 years. Most respondents $(87.4 \%)$ were from non-medical professions, followed by those from the veterinary $(8.6 \%)$ and human medical (4\%) professions. Most respondents (89.4\%) had kept dogs for more than a year. The reasons cited for keeping dogs included protection $(82.8 \%)$, pets $(53 \%)$ and breeding purposes $(4 \%)$. The number of dogs owned ranged from $1-16 ; 78.1 \%$ of respondents owned between one and three dogs. Amongst these respondents, $60.3 \%$ had been visiting a veterinarian for more than a year. Reasons for veterinary visits included treatment of a sick dog (83.4\%), vaccinations and deworming $(80.8 \%)$ and education and guidance on dog health $(45.7 \%)$.

When asked about their general awareness regarding dog zoonoses, $78.8 \%$ of dog owners answered positively (Table 4 ). Of these respondents, a higher proportion (92.4\%) was aware of rabies as a zoonotic disease in dogs compared with other named zoonoses (Table 4). Other zoonoses mentioned were worms $(6.7 \%)$, leptospirosis $(5 \%)$, brucellosis $(1.7 \%)$, ringworm $(0.8 \%)$ and toxoplasmosis $(0.8 \%)$. Those who named leptospirosis as a zoonotic disease in dogs were all from the veterinary profession. A few dog owners responded that tetanus $(0.8 \%)$, fleas $(0.8 \%)$ and ticks $(0.8 \%)$ were zoonoses transmitted by dogs.

\section{Trustworthiness}

For the survey on awareness of dog zoonoses, data were collected using a simple, self-completed, structured questionnaire, which was pre-tested to identify difficult and ambiguous questions. Considering that the majority of the respondents kept dogs and have been visiting veterinary surgeries for over a year, we considered the information provided a true reflection of their awareness of dog zoonoses.

\section{Discussion}

The reference method for serological diagnosis of leptospirosis is the microscopic agglutination test (Levett 2001). However, because of its complexity, rapid screening tests such as the ImmunoComb ${ }^{\circledR}$ ELISA kit (Biogal-Galed Laboratories, Israel) have been developed for detecting leptospiral IgG antibodies in acute infection. Other studies (e.g. Odontsetseg, Sakado

TABLE 4: Dog owners' awareness of dog zoonoses.

\begin{tabular}{lll}
\hline Variable & Number & Percentage \\
\hline General dog zoonoses & 119 & 78.8 \\
Including: & - & - \\
Rabies & 110 & 92.4 \\
Worms & 8 & 6.7 \\
Leptospirosis & 6 & 5.0 \\
Brucellosis & 2 & 1.7 \\
Ringworm & 1 & 0.8 \\
Tetanus & 1 & 0.8 \\
Toxoplasmosis & 1 & 0.8 \\
\hline
\end{tabular}

$n=151$.
\& Kida 2005) reported this test to show a good concordance with the microscopic agglutination test and was suggested as a potential substitute diagnostic test because it was rapid, sensitive and technically less demanding to perform. Because the microscopic agglutination test relies on the use of live attenuated antigens, which require frequent subculturing, it poses a potential risk of infection to the laboratory personnel.

Neither rural nor urban dogs tested in the present study had a history of vaccination against leptospirosis. Currently only urban dogs are vaccinated in the country, using the bivalent vaccine against serovars Canicola and Icterohaemorrhagiae of L. interrogans. Generally, dogs vaccinated against these serovars have negative titres or titres below 1:320, which persist for a few months after vaccination (Hartman et al. 1984). Hence, owing to uncertainty with regard to the vaccination status of some of the urban dogs, a more liberal cut-off point of titres ( $\geq 1: 400$ ) for Leptospira-seropositive dogs was adopted. The ImmunoComb ${ }^{\circledR}$ ELISA kit has a high sensitivity $(80 \%)$, thus reducing the possibility of false negative reactions (http:/ / www.biogal.co.il). Although crossreactivity between antibodies of Leptospira and Borrelia spp. is suspected, it has never been confirmed (Shin et al. 1993); furthermore, lyme disease has not yet been detected in Zimbabwe. The most commonly indicated serovars in canine leptospirosis have been the Canicola, Icterohaemorrhagiae, Pomona, Bratislava and Grippotyphosa types (Greene, Miller \& Brown 1998). Despite its inability to distinguish between the specific serovars, the ImmunoComb ${ }^{\circledR}$ ELISA kit has a mixture of antigens of four of these most common serovars in dogs. Hence, the positive results obtained in the present study are likely to indicate exposure to one or more of these common serovars. However, a lack of serovar-specific data in the present study makes it difficult to conclude on the predominant serovar or serovars and this requires further investigation. The very high titres observed in some of the dogs are likely to indicate acute leptospirosis at or around the time of sampling (Rentko et al. 1992). Interestingly, the highest titre (1:3200, CombScale value 6) was detected in an urban dog with a markedly elevated ALP (5924 IU/L), which provided further support for active leptospirosis that was likely accompanied with hepatic damage. This possibly advocates for a review of the vaccination regime against leptospirosis in urban dogs.

In Zimbabwe there is limited information on canine leptospirosis. The first report was from a case amongst dogs in urban Bulawayo in the south-western part of Zimbabwe during the period 1956-1957 (Graf 1965). A survey in the same urban area demonstrated the presence of the disease in two dogs diagnosed serologically and clinically, and a seroprevalence of 13.7\% (19/146) against serovar Canicola was reported (Banks \& Pigott 1979). The disease was also detected serologically in $2.7 \%$ of dogs but details regarding the number and origin of the samples and the infecting serovar or serovars were not given (Feresu 1982). The serological results of the present study using pooled antigens of the serovars Canicola, Grippotyphosa, Icterohaemorrhagiae and Pomona indicated the presence of leptospirosis in both urban and rural dogs. 
The epidemiology of leptospirosis is mainly influenced by a primary host species that acts as the reservoir for each serovar. Leptospira interrogans serovars such as Canicola and Icterohaemorrhagiae have been reported as the most prevalent in causing canine leptospirosis worldwide (Greene \& Shotts 1990). Dogs and rats are the reservoir species for the Canicola and Icterohaemorrhagiae serovars, respectively (Greene et al. 1998). The widespread use of bivalent vaccines that are specific against only Canicola and Icterohaemorrhagiae has resulted in a decreased prevalence of canine leptospirosis associated with these serovars (Higgins 2004; Prescott et al. 2002). In other regions there have been reports of the apparent re-emergence of canine leptospirosis associated with a change in the infecting serovars (Bolin 1996). The serovars commonly reported are Grippotyphosa and Pomona (Ghneim et al. 2007; Ward, Glickman \& Guptill 2002), with a wide range of wild and domestic animal reservoir species identified (Greene et al. 1998). In Zimbabwe, the serovars Canicola, Icterohaemorrhagiae, Grippotyphosa and Pomona have been detected serologically in pigs (Mavenyengwa, Keller \& Munyombwe 1999), cattle (Feresu 1987, 1988; Graf 1965; Swanepoel et al. 1975) and rodents (Dalu \& Feresu 1997). It is therefore likely that these reservoirs, together with dogs, act as sources of infection for other dogs. However, rats in particular are major sources of infection for humans and dogs and it has been suggested that the serovars present in rodents in a given environment are similar to those present in dogs living in the same environment. Given earlier reports of high rodent seroprevalence (62.5\%) and high serovar isolation, mostly from Rattus rattus, in Harare (Dalu \& Feresu 1997), rats could be considered a major source of infection; however, further investigation is required.

As in earlier studies (Adin \& Cowgill 2000; Alton et al. 2009; Barr 2002), we also observed that seroprevalence of leptospirosis differed between urban and rural dogs, with the former group being at a higher risk for infection. Although these results may be attributable to sampling of dogs with hepatic and/or renal insufficiency presented to private veterinary practitioners, it is likely that leptospirosis in urban dogs may result from contact with infected rodents since a high rodent leptospirosis seroprevalence was previously reported in Harare (Dalu \& Feresu 1997). The greater risk of leptospirosis may reflect the higher density of dogs, rodents and veterinary clinics in the studied urban area. A higher population density of infected raccoons in urban areas of Canada has been implicated as a source of the disease amongst domestic dogs (Alton et al. 2009). To date, no rural comparative studies on rodent leptospirosis have been conducted in Zimbabwe. There is, therefore, a need for further studies to better understand the epidemiology of leptospirosis in both urban and rural settings. The failure to detect any overall association between the sex of dogs and leptospirosis seropositivity in the current study agrees with published reports of leptospirosis in other regions (Suepaul et al. 2010; Ward 2002; Ward et al. 2002).

Infection with serovar Icterohaemorrhagiae has classically been associated with either acute haemorrhagic disease or liver failure and uraemia (Wohl 1996). In contrast, patients with classic infections from serovar Canicola are likely to exhibit acute renal failure associated with less hepatic involvement (Wohl 1996). Infections from serovars Pomona, Grippotyphosa and Bratislava have recently been reported to be predominantly associated with renal involvement and less consistent hepatic involvement (Adin \& Cowgill 2000; Birnbaum et al. 1998; Brown et al. 1996; Okewole \& Ayoola 2009). The significant association observed between Leptospira seropositivity and hepatic and/or renal insufficiency may further be indicative of infection with the tested serovars. Most of the urban seropositive dogs had both hepatic and renal insufficiency, which could probably be attributed to either Icterohaemorrhagiae and/or Canicola infection. For those that had hepatic insufficiency, serovar Icterohaemorrhagiae could probably be the only causative agent, whilst the Canicola, Grippotyphosa or Pomona serovars may not be ruled out for those with renal insufficiency. However, since the serological test used in this study lacked serovar specificity and no isolation was performed, other causes of hepatic and renal insufficiency could not be ruled out. Currently, routine serodiagnosis of leptospirosis is not performed in the country and it is likely that the disease is missed. In view of the emerging new serovars and zoonotic risks posed by the disease, further epidemiological studies are required to identify the prevailing $L$. interrogans serovars in dogs in Zimbabwe. This will enable formulating appropriate control measures against the disease, such as the use of a polyvalent commercial vaccine that includes the new serovars.

Except for respondents in the veterinary profession, results of the present study concur with earlier observations (Mosalagae, Pfukenyi \& Matope 2011; Pfukenyi et al. 2010) that dog owners in Zimbabwe are more aware of rabies as a zoonotic disease than other diseases (e.g leptospirosis). One weakness of the current study is that no correlation could be made regarding Leptospira seropositivity amongst dogs and owners' awareness of zoonoses, since the questionnaires were not administered to the owners of the dogs sampled. However, considering the number of respondents $(5 \%)$ that were aware of leptospirosis as a zoonosis, it is possible that the general awareness amongst pet owners is low. Hence, awareness, teaching and training programmes for pet owners need to be instituted to improve disease control and reduce the public health risk of pet zoonoses such as leptospirosis.

\section{Conclusion}

Although further surveys in other areas of the country still need to be undertaken, the results from this study have shown that leptospirosis was present and represented a risk to dogs from urban Harare and the selected rural communities in Zimbabwe. The significantly higher seroprevalence amongst dogs from Harare compared with those from rural areas may be indicative of differences in area-level risk factors. Sex was not identified as a risk factor for leptospirosis. It is suggested that the use of Leptospira vaccines containing the serovars Canicola and Icterohaemorrhagiae should be continued, whilst investigations with regard to other infecting serovars are undertaken, as such data are lacking. It is also 
recommended that teaching and training programmes for pet owners need to be instituted to improve disease control and reduce the public health risk of pet zoonoses.

\section{Acknowledgements}

The authors are grateful to the Council for Assisting Refugee Academics (CARA) and the AWARE Trust of Zimbabwe for funding this project. Dr M. Tivapasi and the staff at Diagnopath (Pvt) Ltd are thanked for their technical support. Part of this research was supported by funds from the University of Zimbabwe Research Board Grant no. RB/103/11.

\section{Competing interests}

The authors declare that they had no financial or personal relationships that may have inappropriately influenced them in writing this manuscript.

\section{Authors' contributions}

G.M. (University of Zimbabwe) was the project leader and responsible for the study design and drafting the manuscript. D.M.P. (University of Zimbabwe) was the project co-leader and was responsible for the study design and statistical analysis. S.D. (University of Zimbabwe), L.M. (AWARE Trust) and K.D. (AWARE Trust) were responsible for designing the questionnaire, sample collection and testing, literature review and drafting the manuscript.

\section{References}

Adin, C.A. \& Cowgill, L.D., 2000, 'Treatment and outcome of dogs with leptospirosis: 36 cases (1990-1998)', Journal of the American Veterinary Medical Association 216(3), 371-375. http://dx.doi.org/10.2460/javma.2000.216.371, PMid:10668536

Adler, B. \& Moctezuma, A.P., 2010, 'Leptospira and leptospirosis', Veterinary Microbiology 140, 287-296. http://dx.doi.org/10.1016/j.vetmic.2009.03.012, PMid:19345023

Alton, G.D., Berke, O., Reid-Smith, R., Ojkic, D. \& Prescott, J.F., 2009, 'Increase in seroprevalence of canine leptospirosis and its risk factors, Ontario 1998-2006', Canadian Journal of Veterinary Research 73(3), 167-175. PMid:19794888

Banks, P.M. \& Pigott, C.M., 1979, 'An investigation of leptospirosis of dogs in Bulawayo', Rhodesia Veterinary Journal 10, 17-19.

Barr, S.C., 2002, 'Leptospirosis: New issues and considerations', Compendium for the Continued Education in Veterinary Practice 24(1), 53-56.

Birnbaum, N., Barr, S.C., Center, S.A., Schermerhorn, T., Randolph, J.F. \& Simpson, K.W., 1998, 'Naturally acquired leptospirosis in 36 dogs: Serological and clinicopathological features', Journal of Small Animal Practice 39, 231-236. http:// dx.doi.org/10.1111/j.1748-5827.1998.tb03640.x, PMid:9631358

Bolin, C.A., 1996, 'Diagnosis of leptospirosis: A re-emerging disease of companion animals', Seminars in Veterinary Medicine and Surgery (Small Animals) 11(3), 166-171. http://dx.doi.org/10.1016/S1096-2867(96)80029-6

Brown, C.A., Roberts, A.W., Miller, M.A., Davis, D.A., Brown, S.A., Bolin, C.A. et al., 1996, 'Leptospira interrogans serovar Grippotyphosa infection in dogs', Journa of the American Veterinary Medical Association 209, 1265-1267. PMid:8837647

Bulach, D.M., Zuerner, R.L., Wilson, P., Seemann, T., McGrath, A., Cullen, P.A. et al., 2006, 'Genome reduction in Leptospira borgpetersenii reflects limited transmission potential', Proceedings of the National Academy of Sciences 103(39), 14560-14565. http://dx.doi.org/10.1073/pnas.0603979103, PMid:16973745

Cullen, P.A., Haake, D.A. \& Adler, B., 2004, 'Outer membrane proteins of pathogenic Spirochetes', FEMS Microbiology Reviews 28(3), 291-318. http://dx.doi.org/10.1016/ j.femsre.2003.10.004, PMid:15449605

Dalu, J.M. \& Feresu, S.B., 1997, 'Domestic rodents as reservoirs of pathogenic Leptospira on two city of Harare farms: Preliminary results of bacteriological and serological studies', Belgian Journal of Zoology 127(supplement), 105-112.

Duncan, C., Krafsur, G., Podell, B., Baeten, L.A., LeVan, I., Charles, B. et al., 2012, 'Leptospirosis and tularaemia in raccoons (Procyon lotor) of Larimer Country Colorado', Zoonoses and Public health 59(1), 29-34. http://dx.doi.org/10.1111/ j.1863-2378.2011.01412.x, PMid:21824365

Ellis, W.A., 2010, 'Control of canine leptospirosis in Europe: Time for a change?', Veterinary Record 167, 602-605. http://dx.doi.org/10.1136/vr.c4965, PMid:21257439 Feresu, S.B., 1982, 'Leptospirosis in Zimbabwe', Zimbabwe Science News 16, 228-230.
Feresu, S.B., 1987, 'Serological survey of leptospiral antibodies in cattle in Zimbabwe', Tropical Animal Health and Production 19(4), 209-214. http://dx.doi.org/10.1007/ BF02242118, PMid:3424449

Feresu, S.B., 1988, 'A serological survey to determine the most commonly occurring serovars of Leptospira interrogans in the bovine population of Zimbabwe', Israel Journal of Veterinary Medicine 44(1), 25-30.

Ghneim, G.S., Viers, J.H., Chomel, B.B., Kass, P.H., Descollonges, D.A. \& Johnson, M.L., 2007, 'Use of case-control study and geographic information systems to determine environmental and demographic risk factors for canine leptospirosis', Veterinary
Research 38, 37-50. http://dx.doi.org/10.1051/vetres:2006043, PMid:17074294

Graf, H.T.D., 1965, 'Investigation into the status of leptospirosis in Rhodesia', Central African Journal of Medicine 11, 363-366. PMid:5892849

Greene, C.E. \& Shotts, E.B., 1990, 'Leptospirosis', in C.E. Greene (ed.), Clinical Pathology and Infectious Diseases of the Dog and Cat, pp. 498-507, W.B. Saunders, Philadelphia. PMid:2252091

Greene, C.E., Miller, M.A. \& Brown, C.A., 1998, 'Leptospirosis', in C.E. Greene (ed.), Infectious Diseases of the Dog and Cat, pp. 273-281, W.B. Saunders, Philadelphia. PMid:9840314

Grooms, D., 2006, 'Reproductive losses caused by bovine viral diarrhoea virus and leptospirosis', Theriogenology 66(3), 624-628. http://dx.doi.org/10.1016/j. theriogenology.2006.04.016, PMid:16716386

Hartman, E.G., Van Houten, M., Frik, J.F. \& Van der Donk, J.A., 1984, 'Humoral immune response of dogs after vaccination against leptospirosis measured by an IgM- and IgG-specific ELISA', Veterinary Immunology and Immunopathology 7, 245-254. $\mathrm{http}: / / \mathrm{dx}$.doi.org/10.1016/0165-2427(84)90083-7

Higgins, R., 2004, 'Emerging or re-emerging bacterial zoonotic diseases: Bartonellosis, leptospirosis, Lyme borreliosis, plague', Revue Scientific et Technique 23(2), 569-581.

Levett, P.N., 2001, 'Leptospirosis', Clinical Microbiology Reviews 14(2), 296-326. $\mathrm{http}: / / d x . d o i . o r g / 10.1128 / C M R .14 .2 .296-326.2001$, PMid:11292640

Mavenyengwa, M., Keller, E. \& Munyombwe, T., 1999, 'Seroprevalence of leptospiral antibodies in commercial pigs in the Mashonaland East Province of Zimbabwe', Zimbabwe Veterinary Journal 30, 85-91.

Mosalagae, D., Pfukenyi, D.M. \& Matope, G., 2011, 'Milk producers' awareness of milk-borne zoonoses in selected smallholder and commercial dairy farms of Zimbabwe', Tropical Animal Health and Production 43, 733-739. http://dx.doi. Zimbabwe', Tropical Animal Health and Production
org/10.1007/s11250-010-9761-5, PMid:21120606

Murray, G.L., Srikram, A., Hoke, D.E., Wunder, E.A., Jnr., Henry, R., Lo, M. et al., 2009 'Major surface protein LipL32 is not required for either acute or chronic infection 'Major surface protein LipL32 is not required for either acute or chronic infection
with Leptospira interrogans', Infection and Immunity 77(3), 952-958. http:// with Leptospira interrogans', Infection and Imm
dx.doi.org/10.1128/IAl.01370-08, PMid:19103763

Odontsetseg, N., Sakado, Y. \& Kida, H., 2005, 'Serological surveillance of canine leptospirosis in Mongolia', Veterinary Record 157(4), 120-121. PMid:16040947

Okewole, E.A. \& Ayoola, M.O., 2009, 'Seroprevalence of leptospiral serovars other than Canicola and Icterohaemorrhagiae in dogs in the Southwestern Nigeria', Veterinarski Arhiv 79(1), 87-96.

Pfukenyi, D.M., Chipunga, S.L., Dinginya, L. \& Matenga, E., 2010, 'A survey of pet ownership, awareness and public knowledge of pet zoonoses with particula reference to roundworms and hookworms in Harare, Zimbabwe', Tropical Animal Health and Production 42, 247-252. http://dx.doi.org/10.1007/s11250-009-9413-9, PMid:19688308

Plesko, I. \& Hlavata, Z., 1971, 'Cross immunity studies with lipase negative strains of leptospires', Biologia (Bratislava) 26, 689-693.

Prescott, J.F., McEwen, B., Taylor, J., Woods, J.P., Abrams-Ogg, A. \& Wilcock, B., 2002, 'Resurgence of leptospirosis in dogs in Ontario: Recent findings', Canadian Veterinary Journal 43, 955-961. PMid:12561690

Rentko, V.T., Clark, N., Ross, L.A. \& Schelling, S.H., 1992, 'Canine leptospirosis: A

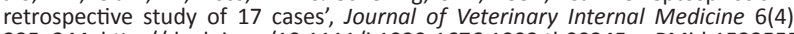
235-244. http://dx.doi.org/10.1111/j.1939-1676.1992.tb00345.x, PMid:1522555

Roach, J.M., Van Vuuren M. \& Picard, J.A., 2010, 'A serological survey of antibodies to Leptospira species in dogs in South Africa', Journal of the South African Veterinary Leptospira species in dogs in South Africa', Jo
Association 81(3), 156-159. PMid:21247041

Shin, S.J., Chang, Y.F., Jacobson, R.H., Shaw, E., Lauderdale, T.L., Appel, M.J. et al., 1993, 'Cross-reactivity between $B$. burgdorferi and other spirochetes affects specificity of serotests for detection of antibodies to the Lyme disease agent in dogs', Veterinary Microbiology 36, 161-174. http://dx.doi.org/10.1016/0378dogs', Veterinary
$1135(93) 90137-\mathrm{V}$

Suepaul, S.M., Carrington, C.V.F., Campbell, M., Borde, G. \& Adesiyun, A.A., 2010, 'Serovars of Leptospira isolated from dogs and rodents', Epidemiology and Infection 138(7), 1059-1070. http://dx.doi.org/10.1017/S0950268809990902, PMid:19811697

Swanepoel, R., Blackburn, N.K., Lander, K.P., Vickers, D.B. \& Lewis, A.R., 1975, 'An investigation of infectious infertility and abortion of cattle', Rhodesia Veterinary Journal 6, 42-55.

Sykes, J.E., Hartmann, K., Lunn, K.F., Moore, G.E., Stoddard, R.A. \& Goldstein, E., 2011, 'ACVIM small animal consensus statement on leptospirosis: Diagnosis, epidemiology, treatment, and prevention', Journal of Veterinary Internal Medicine 25(1), 1-13. http://dx.doi.org/10.1111/j.1939-1676.2010.0654.x, PMid:21155890

Ward, M.P., 2002, 'Clustering of reported cases of leptospirosis among dogs in the United States and Canada', Journal of Preventive Medicine 56(3), 215-226.

Ward, M.P., Glickman, L.T. \& Guptill, L.F., 2002, 'Prevalence of and risk factors for leptospirosis among dogs in the United States and Canada: 677 cases (1970-
1998)', Journal of the American Veterinary Medical Association 220, 53-58. http:// dx.doi.org/10.2460/javma.2002.220.53, PMid:12680448

Wohl, J.S., 1996, 'Canine leptospirosis', Compendium 18, 1215-1222. 